\title{
CORN IRRIGATION WITH RECLAIMED MUNICIPAL WASTEWATER
}

\section{A. PANORAS ${ }^{*}$}

G. EVGENIDIS 1

S. BLADENOPOULOU 1

V. MELIDIS ${ }^{1}$

A. DOITSINIS ${ }^{2}$

\section{SAMARAS ${ }^{1}$}

\section{A. ZDRAGKAS ${ }^{1}$}

Th. MATSI ${ }^{1}$

\author{
${ }^{1}$ NAGREF, Land Reclamation Institute \\ 57400 Sindos Thessaloniki, Greece \\ 2 PEGEAL, Ministry of Agriculture Laboratory \\ 57400 Sindos Thessaloniki, Greece
}

Selected from papers presented at the $7^{\text {th }}$ Conference on Environmental Science and Technology,

3 - 6 September 2001, Ermoupolis, Syros island, Greece. *to whom all correspondence should be addressed

fax: +30-2310 796352 e-mail: panoras.Iri@nagref.gr

\section{ABSTRACT}

The effects of effluent from Thessaloniki, the second most populated Greek city, reclaimed either by activated sludge or by stabilization ponds, were studied on field-grown corn. The experimental layout was that of a split- plot design with six replications, three water qualities and two irrigation methods. Potable water was used as the control. No significant differences in corn yield have been observed among the three water-quality treatments. However, significant differences have been observed in corn yield between the irrigation methods. Furrow irrigation has produced about $10 \%$ more corn yield than trickle irrigation. There is a potential risk of facing problems related to soil salinity and alkalinity if no consideration for soil reclamation is taken into account. The trace element concentration in the soil and plant was low. The chlorinated effluent was free of pathogens, while the presence of pathogens was detected in the non-chlorinated effluent reclaimed by the stabilization ponds.

KEYWORDS: Greece, furrow, drip

\section{INTRODUCTION}

Water resources are steadily declining in arid and semi arid regions where corn is among the most important crops. Municipal wastewater could be an important alternative source for corn irrigation. The use of wastewater for irrigation has the additional benefit of environmental protection (Oron et al.,1992; Pescod, 1992).

Agricultural and landscape irrigation can offer significant opportunity for wastewater reuse, in arid and semiarid regions, since 70 to $90 \%$ of water resources are used for irrigation (Bouwer, 1993; Asano, 1994; Shelef and Azov, 1995).

In Tunisia, the available quantity of reclaimed municipal wastewater for irrigation will reach 125 $\mathrm{Mm}^{3}$ very soon (Bahri, 1988), while 82,900 hectares are already irrigated with wastewater in Mexico (Strauss and Blumenthal, 1989). In the 
USA, the reuse of treated sewage effluent releases $0.76 \mathrm{Mm}^{3}$ day $^{-1}$ of fresh water (Pescod, 1992). In California, more than $70 \%$ of reclaimed municipal wastewater is used for irrigation. (California State Water Resources Control Board, 1990). Reclaimed municipal wastewater plays an important role in Israel's agriculture where $72 \%$ of this water is used for irrigation (Shelef, 1990; Shelef and Azov, 1995).

At the present time, no intentional use of wastewater for irrigation is taking place in Greece. However, extensive wastewater use for irrigation is taking place by discharging the effluent to a receiving water body (Panoras and Ilias, 1999). The number of municipal wastewater treatment plants expected to be in operation by the end of 2000 is 270 with an expected discharge of 1.65 $\mathrm{Mm}^{3}$ day $^{-1}$ (Technical Chamber of Greece, 1993). A significant quantity of this volume can be used for irrigation purposes resulting in economic and environmental profit.

The objective of this research was to study the possibility of reusing the reclaimed municipal wastewater of Thessaloniki, Greece $\left(170,000 \mathrm{~m}^{3}\right.$ day $^{-1}$ wastewater) either by stabilization ponds or by activated sludge for corn irrigation rather than discharging it into the Thessaloniki Gulf. More specifically the effect of two wastewater qualities on corn performance and soil quality were studied using furrow and trickle irrigation.

\section{MATERIALS AND METHODS}

The experiment was carried out during the 1999 growing season in the Thessaloniki plain $\left(40^{\circ} 40^{\prime}\right.$ latitude, $22^{\circ} 48^{\prime}$ longitude) located in the northern part of Greece. The soil profile, to a depth of $90 \mathrm{~cm}$, consists of about $43 \%$ silt, $50 \%$ sand, and $7 \%$ clay. The soil is classified as a sandyloamloam and the bulk density of the soil is around $1.40 \mathrm{~g} \mathrm{~cm}^{-3}$ with a soil water content at field capacity (-0.03 Mpa) and permanent wilting point $(-1.5$ Mpa) of around 24 and $10 \%$ by weight, respectively.

The experimental layout was that of a split plot design with six replications, three water qualities (main plots) and two irrigation methods. Each plot consisted of four rows of corn with a length of $7 \mathrm{~m}$. The distance between rows was $80 \mathrm{~cm}$ with $20 \mathrm{~cm}$ spacing between the plants in a row. Fertilization of all plots was the same taking into account the soil and water fertility. A local corn commercial single-cross hybrid, FAO 750 (138 days to maturity, called Dias (NAGREF-Cereal Institute) was used and was sown on April 19 and harvested on October 1.

Two wastewater qualities, i) wastewater treated by stabilization ponds and sand filtration without disinfection (Wsp), and ii) wastewater treated by activated sludge and chlorination of the effluent (Was) were used for irrigation. Fresh water from a nearby deep well served as control (Wf). The characteristics of water quality were monitored during the experimental period.

The water analysis included biodegradable oxygen demand $\left(\mathrm{BOD}_{5}\right)$, chemical oxygen demand (COD), total suspended solids (TSS), $\mathrm{pH}, \mathrm{EC}$, $\mathrm{Na}, \mathrm{Ca}$ and $\mathrm{Mg}$ yielding qualities with different values for SAR, trace elements, N, P, K, total and fecal coliforms.

A comprehensive soil sampling operation was conducted before sowing and after harvest at depths of 0-30, 30-60 and $60-90 \mathrm{~cm}$. The soil samples were analyzed for $\mathrm{pH}, \mathrm{ECe}, \mathrm{Na}, \mathrm{Ca}, \mathrm{Mg}$ (yielding SAR), and trace elements. Determinations of the soil texture, field capacity, permanent wilting point and volumetric dry weight were carried out at the above mentioned depths before sowing.

The choice of furrow and trickle irrigation was based on the fact that both of these popular methods are used by the farmers all over the world.

With respect to the level furrows with blocked ends precision land leveling was achieved by application of laser techniques. Water was delivered through a $75 \mathrm{~cm}$ pipe system with $2.5 \mathrm{~cm}$ plastic orifices. The pipe network was equipped with valves and flow meters.

In trickle-irrigated plots, water distribution lines, (20 $\mathrm{mm}$ in diameter) were installed in every plant row. The build-in emitters coded GR were labyrinth type produced by Eurodrip S.A. The nominal pressure, the flow rate and the spacing of the unregulated GR emitters were $10 \mathrm{~m}, 4 \mathrm{l} \mathrm{h}^{-1}$, and $33 \mathrm{~cm}$ respectively. Every three laterals were equipped with flow meters, pressure valves and pressure gauges. Gravel and screen filters (120 mesh) were installed at the control station. Filters with a finer screen tend to clog frequently, increasing the head losses within the filter and causing a reduction in the discharge rate (Oron et al., 1980).

Irrigation scheduling was based on the daily computation of crop evapotranspiration except for the 
first irrigation which was based on replacing depleted soil moisture based on soil samples. Also, soil samples were taken at three depths for determining the soil moisture levels at the beginning and the end of the growing period. To enhance germination, all plots were irrigated by sprinkle irrigation applying $27.5 \mathrm{~mm}\left(275 \mathrm{~m}^{3} \mathrm{ha}^{-1}\right)$ fresh water (Wf).
An automated meteorological station next to the field was used for computing reference evapotranspiration using the FAO Penman-Montieth method (Smith, 1992). The depth of water applied to the field was $718.1 \mathrm{~mm}$ or $7181 \mathrm{~m}^{3} \mathrm{ha}^{-1}$ (Table 1). The crop consumed an additional depth of $68 \mathrm{~mm}$ $\left(680 \mathrm{~m}^{3} \mathrm{ha}^{-1}\right)$ soil water during the growing period.

Table 1. Depth of water available to the corn field

\begin{tabular}{cccccc}
\hline $\begin{array}{c}\text { Wsp+Wf } \\
\left(\mathrm{m}^{3} \mathrm{ha}^{-1}\right)\end{array}$ & $\begin{array}{c}\text { Was +Wf } \\
\left(\mathrm{m}^{3} \mathrm{ha}^{-1}\right)\end{array}$ & $\begin{array}{c}\text { Wf } \\
\left(\mathrm{m}^{3} \mathrm{ha}^{-1}\right)\end{array}$ & $\begin{array}{c}\text { Precipitation } \\
\left(\mathrm{m}^{3} \mathrm{ha}^{-1}\right)\end{array}$ & $\begin{array}{c}\text { Soil moisture } \\
\left(\mathrm{m}^{3} \mathrm{ha}^{-1}\right)\end{array}$ & $\begin{array}{c}\text { Total } \\
\left(\mathrm{m}^{3} \mathrm{ha}^{-1}\right)\end{array}$ \\
\hline $6438+275$ & $6438+275$ & 6713 & 468 & 680 & 7861 \\
\hline
\end{tabular}

Table 2. Water quality used for corn irrigation ${ }^{1}$

\begin{tabular}{ccccc}
\hline Parameters & Units & Wsp & Was $^{2}$ & Wf \\
\hline $\mathrm{BOD}_{5}$ & $\mathrm{mg} \mathrm{O}_{2} \mathrm{l}^{-1}$ & $10.6 \pm 4.0$ & $22.4 \pm 9.6$ & - \\
$\mathrm{COD}$ & $\mathrm{mg} \mathrm{O}^{-1}$ & $86.2 \pm 42.7$ & $94.1 \pm 53.1$ & - \\
$\mathrm{TSS}$ & $\mathrm{mg} \mathrm{l}^{-1}$ & $29.9 \pm 5.1$ & $45.1 \pm 19.8$ & $4.7 \pm 1.9$ \\
$\mathrm{pH}$ & & $7.7 \pm 0.29$ & $7.7 \pm 0.06$ & $7.5 \pm 0.13$ \\
$\mathrm{EC} 2$ & $\mathrm{dS} \mathrm{m}^{-1}$ & $3.0 \pm 0.6$ & $2.0 \pm 0.2$ & $1.1 \pm 0.07$ \\
$\mathrm{SAR}$ & $\left(\mathrm{me} \mathrm{l}^{-1}\right)^{1 / 2}$ & $12.9 \pm 1.9$ & $13.8 \pm 1.9$ & $1.1 \pm 0.4$ \\
$\mathrm{adj} . \mathrm{SAR}$ & $\left(\mathrm{me} \mathrm{l}^{-1}\right)^{1 / 2}$ & $14.9 \pm 2.2$ & $15.4 \pm 1.0$ & $1.3 \pm 0.5$ \\
$\mathrm{~B}$ & $\mathrm{mg} \mathrm{l}^{-1}$ & $0.6 \pm 0.1$ & $0.5 \pm 0.1$ & $0.1 \pm 0.02$ \\
$\mathrm{Cd}$ & $\mathrm{ppb}_{\mathrm{Cu}}$ & $<0.03$ & $<0.03$ & $<0.03$ \\
$\mathrm{Fe}$ & $\mathrm{mg} \mathrm{l}^{-1}$ & $<0.01$ & $<0.01$ & $<0.01$ \\
$\mathrm{~Pb}$ & $\mathrm{mg} \mathrm{l}^{-1}$ & $<0.1$ & $<0.1$ & $<0.1$ \\
$\mathrm{Mn}$ & $\mathrm{mg} \mathrm{l}^{-1}$ & $<0.01$ & $<0.01$ & $<0.01$ \\
$\mathrm{Ni}$ & $\mathrm{mg} \mathrm{l}^{-1}$ & $<0.05$ & $<0.05$ & $<0.05$ \\
$\mathrm{Zn}$ & $\mathrm{mg} \mathrm{l}^{-1}$ & $<0.01$ & $<0.01$ & $<0.01$ \\
\hline
\end{tabular}

1 The total number of water samples during the irrigation period was 5 .

2 Sometimes there were EC values of Was ranged between 4.5 and $4.9 \mathrm{dS} \mathrm{m}^{-1}$ due to the sea intrusion into the sewage system.

Table 3. Mean concentration of nutrients in irrigation water

\begin{tabular}{ccccc}
\hline Parameter & Units & Wsp & Was & Wf \\
\hline $\mathrm{TKN}^{1}$ & $\mathrm{mg} \mathrm{N} \mathrm{l}^{-1}$ & 8.8 & 41.0 & 2.51 \\
$\mathrm{NH}_{4}-\mathrm{N}$ & $\mathrm{mg} \mathrm{N} \mathrm{l}^{-1}$ & 6.2 & 33.6 & 0.03 \\
$\mathrm{~N}_{3}-\mathrm{N}$ & $\mathrm{mg} \mathrm{N} \mathrm{l}^{-1}$ & 8.4 & 1.6 & $8.5^{-1}$ \\
$\mathrm{~N}_{2}-\mathrm{N}$ & $\mathrm{mg} \mathrm{N} \mathrm{l}^{-1}$ & 0.4 & 0.4 & 0.005 \\
$\mathrm{Ntot}^{-1}$ & $\mathrm{mg} \mathrm{N} \mathrm{l}^{-1}$ & 17.6 & 43.0 & 11.02 \\
Ptot & $\mathrm{mg} \mathrm{P} \mathrm{l}^{-1}$ & 4.7 & 3.9 & 0.2 \\
$\mathrm{~K}^{+}$ & $\mathrm{mg} \mathrm{l}^{-1}$ & 45.2 & 44.1 & 3.2 \\
\hline
\end{tabular}

${ }^{1}$ Nitrogen Kjeldahl $\left(\mathrm{NH}_{4}-\mathrm{N}+\right.$ Organic $\left.\mathrm{N}\right)$

${ }^{2}$ The $\mathrm{NO}_{3}-\mathrm{N}$ concentration of Wf was high because of greenhouses' activities in the nearby area

\section{RESULTS AND DISCUSSION}

Evaluation of the suitability of the two wastewater qualities (Wsp, Was) for corn irrigation was made according to their composition (Tables 2,3,4) and the international standards (Maas and Hoffman, 1977; Israeli Ministry of Health, 1979, 1981; Ayers and Westcot, 1985; Page and Chang, 1985; Nakayama and Bucks, 1986; Maas, 1990; Benton et al., 1991). Based on their analysis, these waters are suitable for irrigation and without creating particular problems related to the soil, corn, irrigation systems and human health. However, the rational use of these waters ensures the long-term application to the field avoiding possible problems related to soil salinity, alkalinity or emitter clogging. 
Table 4. Microorganism concentration in irrigation water

\begin{tabular}{|c|c|c|c|c|c|c|}
\hline \multirow[t]{2}{*}{ Coliforms } & \multicolumn{2}{|c|}{ Wsp } & \multicolumn{2}{|c|}{ Was } & \multicolumn{2}{|c|}{ Wf } \\
\hline & count $/ 100 \mathrm{ml}$ & $\%$ & count $/ 100 \mathrm{ml}$ & $\%$ & count $/ 100 \mathrm{ml}$ & $\%$ \\
\hline \multirow[t]{2}{*}{ Total } & $<1000$ & 34 & $15^{*} 10^{1}-40^{*} 10^{2}$ & 100 & $<3$ & 100 \\
\hline & $>1000$ & 76 & & & & \\
\hline \multirow[t]{5}{*}{ Fecal } & $<3-10^{3}$ & 36.8 & $<3$ & 100 & $<3$ & 100 \\
\hline & $10^{3}-5.10^{3}$ & 34.2 & & & & \\
\hline & $5.10^{3}-10^{4}$ & 13.1 & & & & \\
\hline & $10^{4}-10^{5}$ & 15.7 & & & & \\
\hline & $>10^{5}$ & 0.2 & & & & \\
\hline
\end{tabular}

The statistical analysis (Table 5) of corn yield and crop height indicate that no significant differences in relation to corn yield were observed between the three water-quality treatments. On

Table 5. Statistical analysis of corn yield

\begin{tabular}{ccc}
\hline Treatment & $\begin{array}{c}\text { Crop height } \\
\text { (cm) }\end{array}$ & $\begin{array}{c}\text { Corn yield } \\
\text { (tn ha-1) }\end{array}$ \\
\hline WspF & $222.1 \mathrm{a}$ & $8.24 \mathrm{a}$ \\
WspD & $227.9 \mathrm{a}$ & $7.86 \mathrm{a}$ \\
WasF & $206.7 \mathrm{~b}$ & $8.98 \mathrm{a}$ \\
WasD & $220.0 \mathrm{a}$ & $7.92 \mathrm{a}$ \\
WfF & $207.1 \mathrm{~b}$ & $9.11 \mathrm{a}$ \\
WfD & $197.1 \mathrm{c}$ & $7.93 \mathrm{a}$ \\
& & \\
Wsp & $225.0 \mathrm{a}$ & $8.05 \mathrm{a}$ \\
Was & $213.3 \mathrm{~b}$ & $8.45 \mathrm{a}$ \\
Wf & $202.1 \mathrm{c}$ & $8.52 \mathrm{a}$ \\
& & \\
F & $211.9 \mathrm{a}$ & $8.78 \mathrm{a}$ \\
T & $215.0 \mathrm{~b}$ & $7.90 \mathrm{~b}$ \\
CV $(\%)$ & 4.9 & \\
\hline
\end{tabular}

Yields with same letters are not significantly different at a 5\% level according to Duncan multirange test.

Wsp = reclaimed municipal wastewater by stabilization ponds

Was = reclaimed municipal wastewater by active sludge

$\mathrm{Wf}=$ fresh water, control

$\mathrm{F}=$ level furrows with blocked ends

$\mathrm{T}=$ trickle irrigation the other hand, there were significant differences in crop height among treatments. Significant differences in corn yield and crop height were observed between furrow and trickle irrigation. Furrow irrigation has produced $10 \%$ more corn yield than trickle irrigation. The irrigation frequency was the same between furrow and trickle irrigation. The statistical analysis of the corn yield and crop height in relation to water quality or irrigation method indicate that the higher the plant, the less seed it produced. Although corn breeders have reported a positive correlation between plant height and yield, there are experimental results where no or negative correlation has been observed (Hallauer and Sears, 1969; Stuber et al., 1969; Alvaro and Crame, 1972).

The total amount of nutrients $(\mathrm{N}, \mathrm{P}, \mathrm{K})$ applied to the field through the irrigation water is shown in Table 6. Values in this table indicate that farmers can save significant quantities of chemical fertilizers. In terms of soil salinity, the use of wastewater increased the ECe regardless of irrigation method (Table 7). Although the winter rainfall reduces soil salinity, soil salinity should to be checked regularly regardless of irrigation method. In relation to soil sodicity, the same behavior has been observed as for the soil salinity (Table 7). Particularly in plots treated with furrow irrigation, the ESP values are much greater than the ones in the trickle treatment.

The increase of the ECe and ESP indicate that careful management and monitoring are required

Table 6. Total amount of nutrients applied to the field through the irrigation water

\begin{tabular}{cccc}
\hline Nutrients & \multicolumn{3}{c}{$\mathbf{N}, \mathbf{P}, \mathbf{K}$ in $\mathbf{~ k g} / \mathbf{h a}$ per water quality } \\
\cline { 2 - 4 } & Wsp+Wf & Was +Wf & Wf \\
\hline N total & 116 & 280 & 74 \\
P total & 30 & 25 & 1 \\
K & 292 & 285 & 22 \\
\hline
\end{tabular}


Table 7. Effect of wastewaters on the ECe and ESP values

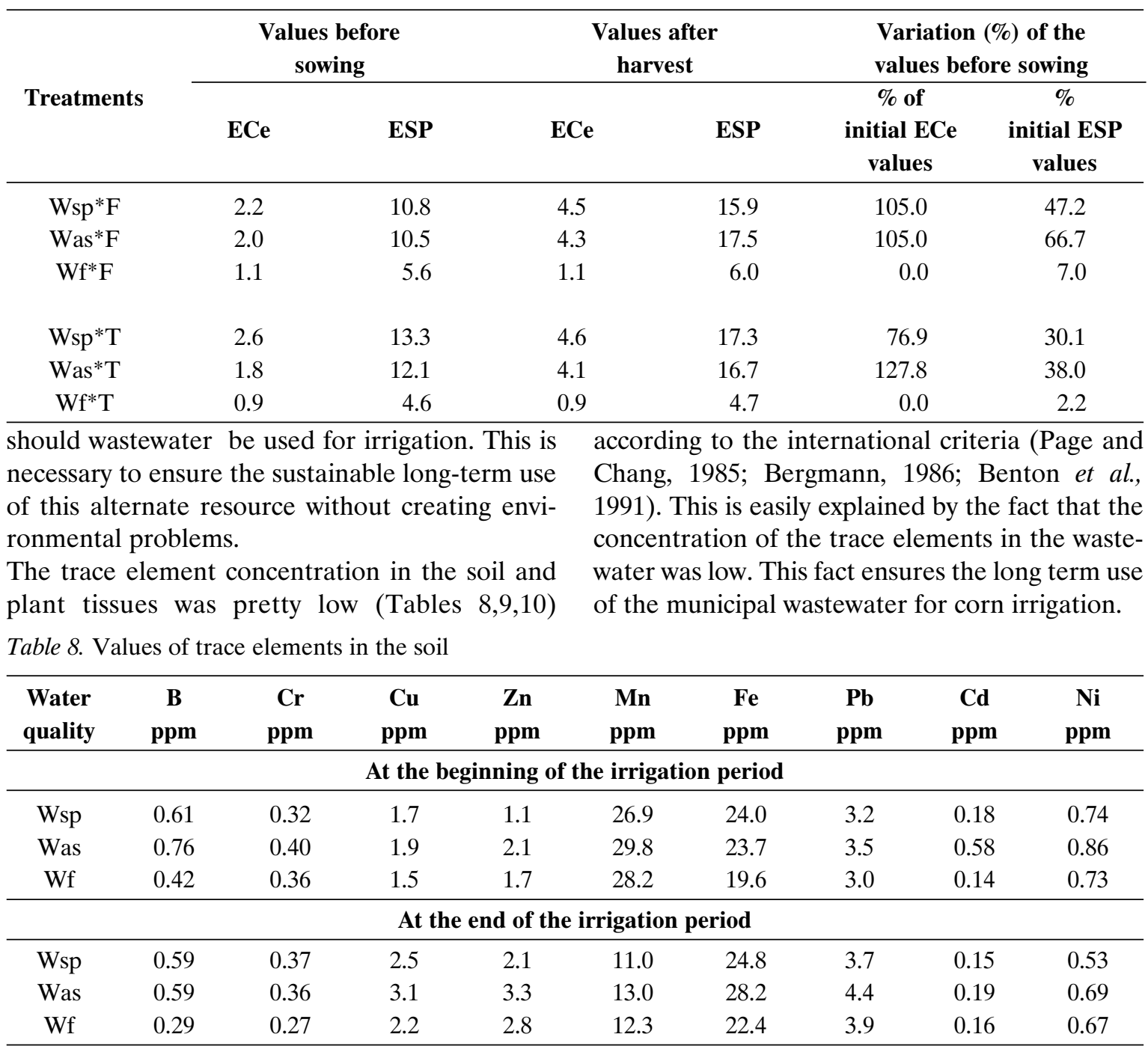

Table 9. Concentration of trace elements in the corn leaves

\begin{tabular}{cccccccccc}
\hline $\begin{array}{c}\text { Water } \\
\text { quality }\end{array}$ & $\begin{array}{c}\mathbf{8} \\
\mathbf{n p m}\end{array}$ & $\begin{array}{c}\mathbf{C r} \\
\mathbf{p p m}\end{array}$ & $\begin{array}{c}\mathbf{C u} \\
\mathbf{p p m}\end{array}$ & $\begin{array}{c}\mathbf{Z n} \\
\mathbf{p p m}\end{array}$ & $\begin{array}{c}\mathbf{M n} \\
\mathbf{p p m}\end{array}$ & $\begin{array}{c}\mathbf{F e} \\
\mathbf{p p m}\end{array}$ & $\begin{array}{c}\mathbf{P b} \\
\mathbf{p p m}\end{array}$ & $\begin{array}{c}\mathbf{C d} \\
\mathbf{p p m}\end{array}$ & $\begin{array}{c}\mathbf{N i} \\
\mathbf{p p m}\end{array}$ \\
\hline Wsp & 15.9 & 5.8 & 17.7 & 26.6 & 63.7 & 388.9 & 1.8 & 4.8 & 9.7 \\
Was & 19.4 & 5.9 & 17.5 & 30.3 & 66.8 & 345.8 & 1.6 & 4.9 & 11.1 \\
Wf & 16.4 & 3.4 & 19.3 & 29.6 & 66.4 & 369.3 & 2.0 & 5.3 & 11.2 \\
\hline
\end{tabular}

Table 10. Concentration of trace elements in the corn ears

\begin{tabular}{|c|c|c|c|c|c|c|c|c|c|}
\hline \multirow{2}{*}{$\begin{array}{l}\text { Water } \\
\text { quality }\end{array}$} & \multicolumn{9}{|c|}{ At the end of the irrigation period } \\
\hline & $\begin{array}{c}\text { B } \\
\text { ppm }\end{array}$ & $\begin{array}{c}\mathrm{Cr} \\
\text { ppm }\end{array}$ & $\begin{array}{c}\mathrm{Cu} \\
\mathbf{p p m}\end{array}$ & $\begin{array}{c}\mathbf{Z n} \\
\text { ppm }\end{array}$ & $\begin{array}{c}\text { Mn } \\
\text { ppm }\end{array}$ & $\begin{array}{c}\mathbf{F e} \\
\text { ppm }\end{array}$ & $\begin{array}{c}\mathbf{P b} \\
\text { ppm }\end{array}$ & $\begin{array}{c}\mathbf{C d} \\
\text { ppm }\end{array}$ & $\begin{array}{c}\mathbf{N i} \\
\text { ppm }\end{array}$ \\
\hline Wsp & 4.9 & 3.4 & 2.6 & 29.6 & 1.4 & 36.7 & 3.5 & 2.3 & 1.9 \\
\hline Was & 5.1 & 2.4 & 3.0 & 31.3 & 1.3 & 38.3 & 3.0 & 1.9 & 2.4 \\
\hline Wf & 5.6 & 1.8 & 3.4 & 30.1 & 1.6 & 36.9 & 2.8 & 2.3 & 3.0 \\
\hline
\end{tabular}


There is no indication of a potential health risk from the reuse of the wastewater reclaimed by activated sludge for irrigation (Table 4) because no pathogenic microorganisms were detected in the chlorinated effluent. Furthermore, both the level furrows with blocked ends and the trickle irrigation system adequately protect the farmers from having physical contact with the water. In the case of the stabilization ponds with no effluent disinfection, there is of course a potential health risk. Chlorination of this effluent is suggested if this water becomes the farmers choice of use.

\section{CONCLUSIONS}

The evaluation of the results related to the corn yield in conjunction with the water quality and irrigation method indicates that the Thessaloniki's municipalwastewater treated either by stabilization ponds or by activated sludge can be reused in corn irrigation under certain precautions. This use will protect the Gulf of the Thessaloniki city from pollution. Also, both furrow and trickle irrigation can be used by the corn growers. Despite the good productivity achieved by irrigating the corn fields with these waters, monitoring the effluent and the soil is necessary in any future wastewater projects.

\section{REFERENCES}

Alvaro, A.E. and Crane, P.L. (1972), Further selection for lower ear height in maize, Crop Science, 12, $165-167$.

Asano, T. (1994), Irrigation with treated sewage effluents, In: Series in Agricultural Sciences (K.K. Tanji and B. Yaron, eds.) Ch. 9, Springer-Verlag, Berlin, Heidelberg, Germany.

Ayers, R.S. and Westcot, D.W. (1985), Water quality for agriculture, F.A.O. Irrigation and Drainage Paper 29, 99-104, Rev.1.

Bahri, A. (1988), Present and future state of treated wastewaters and sewage sludge in Tunisia, Proceedings of Wastewater Reclamation and Reuse, Cairo, Egypt, 11-16 December.

Benton, J.J.Jr., Wolf, B. and Mills, H., A. (1991), Plant analysis handbook - A practical sampling, preparation, analysis and interpretation guide, Micro-Macro Publishing, Inc., USA.

Bergmann, W. (1986), Ernahrungs-storungen bei Kulturphlanzen Visuelle und Analytische Diagnose, Veb Gustav Fischer Verlag, Jena.

Bouwer, H. (1993), From sewage farm to zero discharge, Journal of European Water Pollution Control, 3, 9-16.

California State Water Resources Control Board (1990), California municipal wastewater reclamation in 1987, Sacramento, California.

Hallauer, A.R. and Sears, J.H. (1969), Mass selection for yield in two varieties of maize, Crop Science, 9, 47-50.

Israeli Ministry of Health (1979), Recommendations for treatment of wastewater to be used for irrigation, Israel, Ministry of Health, November.

Israeli Ministry of Health (1981), Public health law No 4263, Purification of sewage water to be used for irrigation, Israel, Ministry of Health, August.

Maas. E.V. (1990), Crop salt tolerance, In: Agricultural Salinity Assessment and Management Manual. K.K. Tanji (ed.), A.S.C.E., New York.

Maas, E.V. and Hoffman, G.J., (1977), Crop salt tolerance, Current assessment, Journal Irrigation and Drainage Division, A.S.C.E., 103, 115-134.

Nakayama, F.S. and Bucks, D.A. (1986), Trickle irrigation for crop production, design, operation and management, Elsevier, Amsterdam.

Oron, G., DeMalach, Y., Hoffman, Z. and Manor, Y. (1992), Effect of effluent quality and application method on agricultural productivity and environmental control, Water Science Technology, 26, 1593-1602.

Oron, G., Shelef, G. and Benjamin, Z. (1980), Stormwater and reclaimed effluent in trickle irrigation, Journal of the Irrigation and Drainage Division, A.S.C.E., 106, 299-310.

Page, A.L. and Chang A.C., (1985), Fate of wastewater constituents in soil and groundwater trace elements, In Irrigation with Reclaimed Municipal Wastewater-A guidance manual, Second Edition, Pettygrove, G.S., and Asano, T. (eds.), Lewis Publishers, Inc., Chelsea, MI.

Panoras, A.G. and Ilias, A.K. (1999), Irrigation with reclaimed municipal wastewater. Thessaloniki, Greece, 190p. Pescod, M.B. (1992), Wastewater treatment and use in agriculture. F.A.O. Irrigation and Drainage Paper 47.

Shelef, G. (1990), The role of wastewater in water resources management in Israel, Water Science and Technology, 22, 2081-2089.

Shelef, G., and Azov, Y. (1995), The coming era of intensive wastewater reuse in the Mediterranean region, 
Proceedings of the 2nd International Symposium on Wastewater Reclamation and Reuse. International Association on Water Quality, Iraklio, Crete, Greece, October 17-20, 1:138-146.

Smith, M. (1992), CROPWAT, a computer program for irrigation planning and management. FAO Irrigation and Drainage Paper 46.

Strauss, M. and Blumenthal, U.J. (1989), Human waste use in agriculture and aquaculture, Utilization practices and health perspectives. I.R.C.W.D., Report No. 08/09. International Reference Centre for Waste Disposal, Dubendorf, Switzerland.

Stuber, C.W., Moll, R.H. and Hanson, W.D. (1969), Geneticvariances and interrelationship of six traits in a hybrid population of Zea Mays L., Crop Science, 6, 455-458.

Technical Chamber of Greece, (1993), Required actions for the protection of environment in Greece. 